\title{
A Study on the Educational Status of Tourism Child Labourers in Petra, Jordan
}

\section{Maram M. Al-Frehat}

\author{
Director of Princess Basma Bent Talal Centre for Intangible Heritage, Petra College, \\ For Tourism and Archaeology, Al-Hussein Bin Talal University, P.O. Box 20, Ma'an, Jordan
}

Email: maramfrehat@yahoo.com

\author{
Jebril A. Alhelalat \\ Assistant Professor - Department of Hotel and Tourism Services Management, Petra, \\ College for Tourism and Archaeology, Al-Hussein Bin Talal University, P.O. Box 20, Ma'an, Jordan \\ Corresponding Author Email: jebrilalhelalat@gmail.com
}

Doi:10.5901/mjss.2015.v6n4s2p20

\section{Abstract}

The study seeks to identify the real status of child labour in tourism in the Petra area and the children's cultural and social tendencies through using the descriptive social survey. The study identifies the real status of child labour through revealing the demographic and social characteristics of children working in the field of tourism and the economic and social characteristics of those children and their families, as well as monitoring the set of values those children have pictured, which express their tendencies and stands toward work, education, and future. The study revealed that the majority of the children working in tourism in Petra face educational and health troubles and they are subjected to different types of abuse. As for the characteristics of children working in tourism in Petra, the majority of them come from large families with relatively high monthly income (around or over the national rate), they are residents of Umm Saihoun village, and half of them work permanently between 8-12 hours per day, the majority of them dropped out of school at early age because of their poor academic performance and disinterest of education.

\section{Keywords: child labour; tourism; Petra; education; dropout of school}

\section{Introduction}

The problem of child labour in Jordan represents a great challenge for the official and civil institutions, specifically after the results of the 2008 Department of Statistics survey results have been announced. The survey indicated that there are 32,676 child labourers in Jordan under the age of eighteen. Nonetheless, child labour in the tourism sector emerged as one of the most dangerous types of child labour in view of the tempting environment and the amount of money children earn. Meanwhile, Petra is considered the main tourism attraction in Jordan and, therefore, for child labour in tourism activities.

This study aims to analyse the status of education among child labourers in Petra with specific reference to the reasons and consequences within the scope of the phenomenon and the characteristics of child labourers (social, cultural, economic and demographic). That would contribute to making a scientific reference for the parties concerned with reducing the negative effect of child labour in general and in the educational status of children in particular. .

The importance of this study stems from the increasing growth of this phenomenon over the past few years, which is related to the increase in the tourism volume and activities in Petra. The engagement of children in a work in the tourism sector has contributed to depriving generations of the local community members of their right to education, something that has affected their chances of improving the quality of their lives. Moreover, this phenomenon has negatively affected efforts to protect the archaeological site and Petra because of ignorance and lack of education, as well as the efforts to protect children and tourists.

\section{Literature Review}

The phenomenon of child labour is considered a complex global problem that many countries of the world are facing, especially in developing countries. According to the International Labour Organization (ILO), the concept of child labour 
applies to all the workers in school age and all the children, including males and females, under the age of fifteen. Children work for several reasons; most important of which is poverty and the lack of deterrent laws and practices. According to the ILO (2006) report, there are some 218 million child labourers in the world. This figure might not reflect reality as there are many children, who were not included in theses official statistics as they belong to the category of children who work for families or in agriculture (ILO, 2006).

According to the ILO, child labour is defined as "the harmful work to the physical, psychological, and health of children that deprives them of their childhood, potentials, and dignity" (Al-Raqqad, 2005).

Child labour is prohibited by all the human rights declarations and agreements allover the world. Funnel (2006) referred to the Universal Declaration of Human Rights, the UN declaration of the rights of the child, and the Tourism and Human rights Document. The 1959 UN declaration of the rights of the child stated that

"The child shall be protected against all forms of neglect, cruelty and exploitation. He shall not be the subject of traffic, in any form. The child shall not be admitted to employment before an appropriate minimum age; he shall in no case be caused or permitted to engage in any occupation or employment which would prejudice his health or education, or interfere with his physical, mental or moral development"

In addition, George and Varghese (2007) and Cole and Eriksson (2010) discussed child labour from a human rights point of view. They explained that child prostitution and child labour are among the issues that stand against the sustainability of tourism and its contribution to the welfare of communities.

Having considered sustainable tourism, Koenig (2010) listed the negative effects of tourism, those of which threaten the sustainability of tourism and its contribution to development, in a socio-cultural context; prostitution, child labour, drug trade, human trafficking, and sometimes destroying social life and traditional values of societies.

In the same context, it is thought that tourism should help societies in both economic development and poverty reduction (Koenig, 2010). The millennium development goals in relation to tourism development and poverty illumination stressed on the role of tourism in enhancing economic growth, in providing employment opportunities, in spreading tourism activities to remote and rural areas, and in developing infrastructure, healthcare and welfare of communities in the tourism destinations (Novelli and Hellwig, 2011; Koenig, 2010; Honey and Gilpin, 2009).

The World Tourism Organisation's publications suggest focusing on natural, social, cultural and economic environment reserve and development to help in reducing the phenomenon of child labour. This is to be applied through partnerships between the industry, government and civil societies (mainly non-governmental organizations NGOs). The role of NGOs is salient here, George and Varghese (2007) stressed on the role of NGOs in helping communities to know the rights of women and children.

Sharma, Kukreja and Sharma (2012) recommended that NGOs' mission here should be to push towards prohibition of child labour, getting the children back to school and propose a legislation change to include stronger acts against child labour facilitators.

Tourism activities attract children in a wider range, both boys and girls, all over the world to work in small restaurants and coffee shops. Moreover, the children work as peddlers and as tour guides at tourism and archaeological sites. They also work in cleaning and carrying luggage at hotels, washing dishes and helping at kitchens, while others work in prostitution, and as beggars (David. 2000). Although tourists, emotionally, tend to give money to children who work in tourism activities thinking they are helping them and their families, a note should be given here about type of risks may children face while working. These risks are represented by long working hours, abuses and sexual harassment, and the risk of infections of several diseases, especially AIDS-HIV, which international statistics indicate that it spreads in the local communities surrounding the tourism sites. Moreover, the risks of this work are also related to the discontinuity of work, child abuse and self-inflicted injuries, and working in an unsuitable environment from both health and social aspects (ILO, 2011; David. 2000).

Black (1995) stated that the reasons behind child labour in general were due to poverty, parental unemployment, and instable family situation, such as orphanhood. Majority of children working in tourism prefer such sector because of the easy access, deskilled jobs and the help of relatives or connections to get the access to the industry.

According to the ILO, there are between 13 to 19 million children and youngsters in the world below the age of 18 working in tourism. This figure only covers the organized tourism sector.

The reasons for the increase in the numbers of children working in tourism in the world are linked to the economic and social conditions of the local communities in the tourism sites. The fact that these communities did not have the chance to positively be part of the tourism development process, forced poor families to push their children to work in tourism and to get the advantage of its relatively high income. Meanwhile, child labour is considered cheap labour for employers (Bliss, 2006). Moreover, the seasonality of tourism in various regions in the world has greatly contributed to attracting children during school holidays to work, and in many cases to continue to work and drop out of school 
afterwards. One of the major reasons behind the increase of this problem is the weakness of the governmental procedures in providing education and preventing child labour (Bliss, 2006).

Gordon Brown (2012), as the UN Special Envoy for Global Education, stated that the lost of childhood and psychological and emotional damage of children involved in hazardous employment is a dangerous issue; he stressed that the threat of children dropping out of school before completion will affect their mental and physical abilities as well as their future opportunities of decent employment. He called for a global action to enhance children education that in a way prevents child labour.

In the same context, in 2002, the ILO published a report that discussed the future of child labour in relation to the strong links between child labour, education and poverty. Considering education, ILO (2002) stressed on the fact that the absence of public education systems, quality schools and training programmes opens the door for more child labourers. Accordingly, good education systems can prevent child labour through school readiness, children-friendly schools, flexibility in education to accommodate the needs of children and their families according to their economic status, nonformal education programmes, training of teachers that focus on children-centered teaching approaches and methods, and apprenticeship and vocational education with economic incentives (ILO, 2002).

In Jordan, laws and regulations prohibit anyone under the age of sixteen from working in the formal sector, which represents a minimum age more consistent with the age of compulsory education (Labour Law of 1996 and Education Law of 1988) (Saif, 2004). In 1991, Jordan endorsed the Convention on the Rights of the Child, which is considered the most important international mechanism to reduce child labour internationally. In 1995, Jordan established the National Task Force for Children; the first national report on child labour was issued in 1997. Jordan also officially joined the ILO's International Programme on the Elimination of Child Labour in 2001. As a result, the Child Labour Unit was established at the Labour Ministry, which in turn created a database on child labour in Jordan (USDL, 2004). The 1997 national report mentioned earlier stated that $13 \%$ of boys between the ages of fifteen to sixteen are working, and that $1.1 \%$ of girls of the same age also work. The ILO estimated the rate of child labour in Jordan at less than $1 \%$ among the children between the age of ten and fourteen (Saif, 2004).

In 2008, the national survey on child labour revealed that there were 32,672 children between the ages of five to seventeen are working. This figure represents $1.8 \%$ of the total number of children within this age group. The survey also revealed that the most attractive professions for children were the vocational professions, with less percentage in the primary professions of services and sales. The survey also showed that the average working hours children work per week was 42 hours with an average income that does not exceed 81 Jordanian Dinars (JD) a month (less than \$60). It was revealed in the survey that $42.5 \%$ of these children study at educational institutions, the remaining percentage is considered a dropping out of school number. The dropping out of school was believed to happen due to children's poor academic performance or disinterest in studying (Department of Statistics, 2008).

Darweesh (2000) concluded that the working children belong to large in size families with low parents' educational and economic levels. The study noted that there were negative influences of child labour on the development of the children as a result of their feeling of deprivation of their rights, such as education and playing. Moreover, they negatively develop some bad behaviour patterns such as weaknesses of their personality aspects, tendency to prefer isolation, and aggressiveness toward others.

Gharaibeh and Hoeman (2003) conducted a study on the social and health conditions of working children in Irbid city (north) and found that most of the working children are poor children who dropped out of school to help their families. The study also found out that the health conditions of those children are poorer than their peers on a national scale, and that they are facing physical exhaustion and psychological pressures greater than their abilities and ages could stand.

Over the past ten years, many efforts have been made to combat child labour as part of a programme implemented by the Ministry of Labour, the Ministry of Social Development, the Jordanian Women's Union, the National Council for Family Affairs, and the National Programme on Child Labour, in cooperation with a number of international organizations and agencies, most important of which are the ILO, UNICEF, the United Nations for Relief and Work Agency for Palestinian Refugees (UNRWA), and Save the Children. These activities focused on the problem of child labour in streets, auto repair shops, and carpentry shops. These efforts covered the large cities of Amman, Al-Zarqa, and Irbid. However, these efforts failed to address other sectors that attract children, foremost of which is tourism. Two of the very few studies, out of these previously mentioned, studied child labour in tourism were conducted by Al-Hilalat (2003) and Magableh and Naamneh (2010).

Al-Hilalat (2003) aimed to identify the characteristics of working children and the feature of their families, and to uncover their working conditions as well as identifying the most important health and social repercussions of child labour in Petra. It was found that most of the children working in Petra work as attendants for riding animals and dealers; most of them belong to large in size families with parents of low educational level. The results also indicated that the majority of 
working children work 6 days or less per week with an average of 8.2 hours a day. The most important reason that forced them to work was to assist their families financially and to earn their pocket money.

Magableh and Naamneh (2010) concluded that the majority of the children working in tourism came from poor families and that majority of them came from families with low educational level. As for the educational status of the children themselves, the results indicate that $51 \%$ of them still go to school, and that most of them work in jobs that do not require any skills.

On the other hand, the Jordanian education system requires that the age of compulsory education is between six and sixteen years old (Ministry of Education, 2007), while the Jordanian labour law requires the minimum age of employment at 16 years old (ILO, 2011b); this makes no gap between the compulsory education age and the minimum age of employment. According to the Understanding Children's Work Programme (UCR, 2014), the statistics show that approximately $1 \%$ of children between seven and fourteen years old in Jordan are working with no enrollment in education, compared to $6.4 \%$ in Iraq and $8.6 \%$ in Lebanon.

Due to the negative impact of the phenomenon of child labour in tourism activities in Petra, with specific reference to the United Nations declaration of the rights of children, and the valid Jordanian laws and regulations related to labour and education, this study seeks to present information about the demographic, social, and economic characteristics of the children working in tourism, with an analysis to their educational status and the future consequences.

The results of this study are to be used in forming further steps to reduce child labour in Petra site in general, and to support the efforts of getting those children back to school through a number of practical recommendations.

\section{Methods}

This descriptive study adopted the survey method. Two surveys were developed to achieve the goals of the study. First, a survey relied on one question with the aim of knowing about the real size of child labour inside and outside the archaeological site. This tool was implemented in three different times; the high tourism season in April, the medium tourism season in May, and during the period of low tourism season in July. Second, a large sample survey was developed to answer the research questions through learning about the demographic characteristics, work status, family status, and scholastic status and some related aspect to children education.

Regarding sampling technique, the second survey, which was the main tool of the study, was based on surveying all the population that was available during the data collection time. Overall, the sample size reached 208 children; this number comprises all the children who work in the archaeological site at the time of data collection.

Accordingly, the statistics reached from the sample were grouped and exhibited in tables of frequencies and descriptive statistics to go along with the research aim and descriptive research design.

A final note about data collection and research ethics; it was ensured those parents and other adults around the site where data was collected informed consent and children participated voluntarily. In addition, data was collected in a face-to-face method by the researchers and well trained research assistants. The researchers and assistants filled in the questionnaire to ensure that questionnaires were correctly filled in. moreover; incentives were given to children who participated to enhance more valid contribution.

\section{Results and Discussion}

The results of the study have been analysed based the aspects of: demographic characteristics of children; work status; family status; and educational status of children.

\subsection{The demographic and work profile of child labourers}

The results of gender distribution concluded that the percentage of male working children is higher than females, which are successively $89.4 \%$ and $10.6 \%$. These percentages are consistent with those in the survey on child labour in Jordan conducted by the Department of Statistics, which were successively $89 \%$ and $11 \%$ (Department of Statistics, 2008). This is assumed to be normal due to the masculine culture of the region as males work more than females in such activities. Moreover, the number of formal workers in tourism in Jordan records greater percentage of males (90\%) and low female employment (10\%). Table (1) shows the demographic characteristics of the child labourers sample. 
Table 1. The Demographic status of child labourers in Petra

\begin{tabular}{|l|c|c|c|}
\hline Demographics & $\mathrm{N}$ & Percentage \\
\hline Gender & Male & 186 & $89.4 \%$ \\
\cline { 2 - 4 } & Female & 22 & $10.6 \%$ \\
\cline { 2 - 4 } & Total & 208 & $100 \%$ \\
\hline \multirow{4}{*}{ Age } & Less than 7 years & 1 & $0.5 \%$ \\
\cline { 2 - 4 } & $(7-12)$ & 86 & $41.3 \%$ \\
\cline { 2 - 4 } & $(13-15)$ & 46 & $22.1 \%$ \\
\cline { 2 - 4 } & $(16-18)$ & 75 & $36.1 \%$ \\
\hline Place of Residence & Total & 208 & $100 \%$ \\
\cline { 2 - 4 } & Wadi Mousa & 6 & $2.8 \%$ \\
\cline { 2 - 4 } & Umm Saihoun & 187 & $90 \%$ \\
\cline { 2 - 4 } & Al-Baida & 7 & $3.4 \%$ \\
\cline { 2 - 4 } & Elsewhere & 8 & $3.8 \%$ \\
\hline Type of Work & Total & 208 & $100 \%$ \\
\cline { 2 - 4 } & Horse attendant & 4 & $2 \%$ \\
\cline { 2 - 4 } & Donkey attendant & 50 & $24 \%$ \\
\cline { 2 - 4 } & Camel attendant & 12 & $5.8 \%$ \\
\cline { 2 - 4 } & Peddler & 121 & $58.1 \%$ \\
\cline { 2 - 4 } & Salesman in a shop & 14 & $6.7 \%$ \\
\cline { 2 - 4 } & Worker & 7 & $3.4 \%$ \\
\cline { 2 - 4 } & Total & 208 & $100 \%$ \\
\hline
\end{tabular}

Table (1) also shows that the percentage of the working children whose ages are within the age group (7-12) years, was the highest and represented $41 \%$ of the sample. The age group (16-18) comes second as it represented $36 \%$ of the sample, followed by the age group (13-15) at $22 \%$. Accordingly, the children within the age group (7-15) represent more than $63 \%$ of the sample.

This result does not agree with the survey conducted by the Department of Statistics in which the percentage of working children in the age group (12-17) was the highest representing $90 \%$ of the total number of the working children in Jordan (Department of Statistics, 2008). This affirms that the ages of the children working in the tourism sector in Jordan are low compared to child labour in other sectors, which makes them more vulnerable to risks.

Table (1) illustrates, as well, that the percentage of most of the working children are residing in Umm Saihoun area at $90 \%$ of the size of the sample. The rest of the children are residing in Al-Baida area and Wadi Mousa.

The distribution of children working in tourism by type of work is shown in Table (1). It concludes that the percentage of children working as peddlers was the highest and represented $58 \%$ of the sample, followed by donkey attendants at $24 \%$, and the lowest was for the horse attendants at $2 \%$. The total percentage of the attendants of riding animals and camels represented $66 \%$ of the size of the sample. This illustrates the large numbers of donkeys, horses, and camels present inside the archaeological site.

In relation to the work status of children, table (2) illustrates the distribution of children working in tourism by number of working hours. It indicates that $45.1 \%$ of the children work (7-9) hours, followed by $30 \%$ of the children work longer hours between (10-12) hours. These percentages match those in the study of the phenomenon of child labour in Petra. The children working within the category ( 6 - less than 10 ) hours had the highest percentage at $63.8 \%$, followed by the category (10 and above) hours at $25.3 \%$ (Al-Hilalat, 2003). It is thought that children who work more earn more; that explains why the majority of children work between 7-12 hours.

Table 2. the work status of child labourers in Petra

\begin{tabular}{|l|c|c|c|}
\hline \multicolumn{2}{|l|}{ Work status } & $\mathrm{N}$ & $\%$ \\
\hline Number of Working Hours & $1-3$ & 5 & $2.4 \%$ \\
\cline { 2 - 4 } & $4-6$ & 42 & $20.1 \%$ \\
\cline { 2 - 4 } & $7-9$ & 94 & $45.1 \%$ \\
\cline { 2 - 4 } & $10-12$ & 63 & $30 \%$ \\
\cline { 2 - 4 } & $13-14$ & 5 & $2.4 \%$ \\
\cline { 2 - 4 } & Total & 208 & $100 \%$ \\
\hline
\end{tabular}




\begin{tabular}{|l|c|c|c|}
\hline Continuity of Work & Permanent & 102 & $49.5 \%$ \\
\cline { 2 - 4 } & Seasonal & 25 & $12.1 \%$ \\
\cline { 2 - 4 } & Temporary & 21 & $10.2 \%$ \\
\cline { 2 - 4 } & Intermittent & 58 & $28.2 \%$ \\
\cline { 2 - 4 } & Total & 206 & $100 \%$ \\
\hline
\end{tabular}

This point needs a comment; more than $77 \%$ of children work more than 7 hours, which means a full working day and cannot be considered part-timers. Table (2) also indicates that almost half of working children work permanently at $49.5 \%$, which makes a link between the two issues that the majority of children are fully engaged at a permanent work without perusing neither their childhood nor their education. This is an urgent alert about their future.

\subsection{The family status of child labourers}

Table (3) stresses that most of the children working in tourism have one or more family members working in tourism excluding the working child, and they represent the highest percentage of the size of the sample at around $80 \%$ (the total percentage for 1-6 members and above), and the percentage of the presence of one family member working in tourism was the highest at $33.7 \%$, followed by the presence of two members working in tourism at $23.6 \%$.

Table 3. Family status of child labourers in Petra

\begin{tabular}{|c|c|c|c|c|}
\hline \multicolumn{3}{|l|}{ Family status } & $\mathrm{N}$ & Percentage \\
\hline \multirow{8}{*}{\multicolumn{2}{|c|}{ Number of family members Working in tourism }} & None & 46 & $22.1 \%$ \\
\hline & & One & 70 & $33.7 \%$ \\
\hline & & Two & 49 & $23.6 \%$ \\
\hline & & Three & 22 & $10.6 \%$ \\
\hline & & Four & 15 & $7.2 \%$ \\
\hline & & Five & 1 & $0.5 \%$ \\
\hline & & Six or above & 5 & $2.5 \%$ \\
\hline & & Total & 208 & $100 \%$ \\
\hline \multirow{5}{*}{\multicolumn{2}{|c|}{ Average family Income (in Jordanian Dinars) }} & 500 and less & 71 & $34 \%$ \\
\hline & & $501-1000$ & 87 & $42 \%$ \\
\hline & & $1001-1500$ & 35 & $17 \%$ \\
\hline & & 1501 and above & 15 & $7 \%$ \\
\hline & & Total & 208 & $100 \%$ \\
\hline \multirow[t]{10}{*}{ Educational levels } & \multirow[t]{5}{*}{ Of Fathers } & Illiterate & 84 & $40,4 \%$ \\
\hline & & Reads and writes & 19 & $9.1 \%$ \\
\hline & & Elementary & 74 & $35.6 \%$ \\
\hline & & Secondary & 31 & $14.9 \%$ \\
\hline & & Total & 208 & $100 \%$ \\
\hline & \multirow[t]{5}{*}{ Of Mothers } & Illiterate & 116 & $55.8 \%$ \\
\hline & & Reads and writes & 15 & $7.2 \%$ \\
\hline & & Elementary & 58 & $27.9 \%$ \\
\hline & & Secondary & 19 & $9.1 \%$ \\
\hline & & Total & 208 & $100 \%$ \\
\hline
\end{tabular}

The result was close to the study of the phenomenon of child labour in tourism in Petra in terms of the presence of one family member working in tourism (Al-Hilalat, 2003). It is noticed here that there is an inverse relationship between the number of the working family members and the number of working children, that is, the higher the number of the working family members, the lower the number of working children.

Table (3) clarifies the family monthly income and the total income of working children. The income between (5011000) Dinars was the highest at $42 \%$, followed by the category (500 and less) at $34 \%$. It is noticeable that the level of the total income of families is higher than the average income of the Jordanian families (about $700 \mathrm{JD}$ according to 2010 statistics). This encourages the families to make their children work in this sector.

Table (3) points up the increase in illiteracy among the fathers and mothers of the working children; the percentage of illiteracy for fathers is $40 \%$ and for mothers $55.8 \%$. This might be an indicator of the lack of interest of the parents in 
educating their children because of their low educational level. The illiteracy percentage here is much higher than the national rate that is $6.7 \%$ (Department of Statistics, 2012). It is noted as well that non of the parents of child labourers have a degree, which made a strong emphasis on the assumption that children see their parents as a model.

\subsection{The educational status of child labourers}

Table (4) illustrates that the education level of the working children in the elementary stage is the highest and it represents 53.8\%, and the lowest for the working children in the secondary stage at 9\%; a close percentage between males and females. Meanwhile, there is a percentage of $19.2 \%$ who are illiterate, which indicates a problem in a country with highly educated population such as Jordan.

Table 4. The Distribution of Children Working in Tourism by Educational Level

\begin{tabular}{|l|c|c|c|c|c|c|}
\hline \multirow{2}{*}{ Education Level } & \multicolumn{2}{|c|}{ Males } & \multicolumn{2}{c|}{ Females } & \multicolumn{2}{c|}{ Total } \\
\cline { 2 - 7 } & $\mathrm{N}$ & $\%$ & $\mathrm{~N}$ & $\%$ & $\mathrm{~N}$ & $\%$ \\
\hline Illiterate & 35 & $19 \%$ & 5 & $22.7 \%$ & 40 & $19.2 \%$ \\
\hline Reads and writes & 33 & $17.6 \%$ & 4 & $18.2 \%$ & 37 & $17.8 \%$ \\
\hline Elementary & 100 & $53.8 \%$ & 12 & $54.5 \%$ & 112 & $53.8 \%$ \\
\hline Secondary & 18 & $9.6 \%$ & 1 & $4.5 \%$ & 19 & $9.2 \%$ \\
\hline Total & 186 & $100 \%$ & 22 & $100 \%$ & 208 & $100 \%$ \\
\hline
\end{tabular}

These percentages were in line with the study of the phenomenon of child labour in tourism in Petra which affirmed that the percentage of those who were in the elementary stage was the highest in the educational level of working children (Al-Hilalat, 2003). According to the educational system in Jordan, the age of the elementary stage is between 5 and12; this is the highest age group of child labourers as mentioned earlier.

Table (5) gives an idea about the scholastic status of working children. The results indicate that $41.3 \%$ of the sample dropped out of school, while the remaining percentage still attends school.

Table 5. The Scholastic Status of the Children Working in Tourism

\begin{tabular}{|c|c|c|}
\hline Status & $\mathrm{N}$ & $\%$ \\
\hline Dropped Out of school & 85 & $41.3 \%$ \\
\hline Still Go to School & 121 & $58.7 \%$ \\
\hline Total & 206 & $100 \%$ \\
\hline
\end{tabular}

Table (6) illustrates the distribution of children working in tourism by their continuity to work and scholastic status. It emerges that the children who work permanently are the children who most refrained from going to school than those who work seasonally, temporarily, or intermittently at $83.5 \%$ of those who said that they have dropped out of school. Whereas, the children who work intermittently represented the highest percentage of children who answered yes, that is, they still go to school.

Table 6. The Distribution of Children Working in Tourism by Continuity of Work and Going to School

\begin{tabular}{|c|c|c|c|c|}
\hline \multirow{3}{*}{ Work continuity } & \multicolumn{4}{|c|}{ Do You Go To School? } \\
\hline & \multicolumn{2}{|c|}{ Yes } & \multicolumn{2}{|c|}{ No } \\
\hline & $\begin{array}{c}\mathrm{N} \\
121\end{array}$ & $\begin{array}{c}\text { Percentage } \\
58.7 \%\end{array}$ & $\begin{array}{l}N \\
85\end{array}$ & $\begin{array}{c}\text { Percentage } \\
41.3 \%\end{array}$ \\
\hline Permanent & 31 & $25.6 \%$ & 71 & $83.5 \%$ \\
\hline Seasonal & 19 & $15.7 \%$ & 6 & $7.1 \%$ \\
\hline Temporary & 19 & $15.7 \%$ & 2 & $2.3 \%$ \\
\hline Intermittent & 52 & $43 \%$ & 6 & $7.1 \%$ \\
\hline
\end{tabular}

Table (7) explains the reasons for dropping out of school. The lack of desire to go to school because of the poor academic performance at school represented the highest percentage at $46 \%$. This is followed by the teachers' abuse and for work equally at $13 \%$ for each. This result agrees with the study of the Department of Statistics as the poor academic 
performance was the most important reason for dropping out of school, followed by dropping out of school for work (Department of Statistics, 2008). Also, the results agree with the study of the phenomenon of child labour in tourism as the poor academic performance was the most important reason for dropping out of school (Al-Hilalat, 2003).

Table 7. The Distribution of Children Working in Tourism by Reasons of Dropping Out of School

\begin{tabular}{|l|c|c|}
\hline Reasons for Dropping Out of School & $\mathrm{N}$ & Percentage \\
\hline The lack of incentives & 3 & $3.5 \%$ \\
\hline Because of the Teachers' abuse & 11 & $13 \%$ \\
\hline The lack of desire because of poor academic performance & 39 & $46 \%$ \\
\hline The absence of anyone to help the family & 3 & $3.5 \%$ \\
\hline For work & 11 & $13 \%$ \\
\hline Unwilling parents & 1 & $1 \%$ \\
\hline Below the school age & 1 & $1 \%$ \\
\hline The lack of a clear reason to drop out of school & 16 & $\% 18.8 \%$ \\
\hline Total & 85 & $100 \%$ \\
\hline
\end{tabular}

An overall comment about children's work and education asserts that the lack of academic achievement and the lack of desire to go to school was the reason behind half of the child labourers who dropped out of school. A question raised here about the seriousness of authorities, especially in the education departments, to help in reducing the phenomenon of child labour by giving more help to families and children to attract them to school and to increase their academic performance. The effort of societies and NGOs is required at this stage.

To sum the results up, it was revealed that the majority of working children inside the Petra archaeological site were males, aged between seven to 15 years old, working as peddlers and animal attendants as an easy and unskilled work, and residing mainly in Umm Saihoun village near the site. This was maybe an important result as it indicates that the society of Umm Saihoun needs further deep analysis in relation to the social, economic and cultural aspects to determine the reason behind the $90 \%$ figure of child labourers appeared in the results. In addition, half of the child labourers in Petra are permanent workers with low school attendance, which indicated an important issue related to the future of a large number of children with no education and therefore no protected future. One-third of the population below the poverty line doesn't mean that the low income of families is the main reason behind child labour; considering the family status of child labourers in Petra, low educational level of parents and the need for getting the advantage of the tourism income are assumed to be reasons behind the child labour phenomenon in Petra.

In addition, children working in tourism face a problem regarding education; dropout of school at early age is a result of students disinterest in education and their want to earn money at early age. One-fifth illiterate percentages and just about half of the children do not attend school is a crucial problem that results in creating inactive members in their societies in the future.

\section{Conclusion}

The survey concludes that the scope of child labour in the tourism sector in Petra is continuously increasing with the increase of tourism activities. The study indicated that the average number of working children is 400 , and that it reaches greater number in the high tourist season.

As a main issue, the reasons behind child labour phenomenon in Petra are related to educational and scholastic aspect (high illiteracy among children's parents and lack of children's academic performance and lack of interest of school), social aspects (children seem to act like their fathers and other family members who work in tourism), economic reasons (as one-third of child labour was because of their families' poverty).

In addition, the work of children in the tourism sector in Petra poses a danger to children's future compared to the children working in the other sectors in terms of:

- The high number of children who dropped out of school at an early age for the easiness of doing the work (peddler, donkey attendant, among others).

- The long working hours associated with bad health, physical, and environmental conditions the children suffer at the workplace.

- The bad behavioural habits children acquire through the contact with the tourists and the adult colleagues at the same workplace. 
Moreover, the study affirmed that the number of working children is on the rise inside the archaeological site, which constitutes an element that hinders tourism development and damages the archaeological site.

Finally, the children developed negative tendencies toward school and education; no willingness to attend school as they see work more beneficial. The social status of the children's families encourages them to work at early age because of parents' low educational level and hence low interest in educating their children. In addition, having a percentage of illiterate and children with only elementary education warns for a dangerous effect of child labour on the children's future as well as the future of their society.

\section{Recommendations}

After reviewing the literature and the research analysis and results, the following recommendations were drown out:

First: looking at the economic reason (poverty and low income) as the main and only reason behind the phenomenon in the region is not the right approach to solve it. Hence, partnerships among governmental authorities, NGOs, local people and the tourism industry is needed to discuss the phenomenon and to help in finding creative solutions to resolve it.

Second: the need for enforcing the law that prohibits child labour. It was concluded that there was an absence of any follow-up from the official institutions to enforce the law, regulations, and instructions related to child labour below the legal age. There were unnoticeable serious efforts to force students to complete the compulsory education. In addition, there were little efforts from the local authorities (Petra Development and Tourism Region Authority, Ministry of Interior representatives, Education Directorates) to seriously study the phenomenon and take into consideration recommendations on it.

Third: establishing a governmental body for local development and for supporting childhood in Umm Saihoun area through official initiatives or by the local civil society organizations that would be a local arm for development and encouragement for the children and their families to quit work and return to school. This might include setting a programme for informal education targeting the children who dropped out of school and the children who have poor academic performance. Such programme would contribute to the rehabilitation of the children to continue studying at school or return to it.

Fourth: launching awareness programmes and spreading a friendly culture concerned with the children's right to education that target the local communities, as well as launching similar programmes that target the community at the archaeological site, tourists and business owners regarding the phenomenon.

Fifth: launching programmes for supporting the improvement of the environment of schools in the areas of Umm Saihoun, Al-Baida, and Wadi Mousa so that they would be more attractive to children.

Sixth: developing training programmes for teachers to help them acquiring new skills that would enable them to deal with children who are vulnerable to risks.

Seventh: further research is recommended to deeply study the economic, social and cultural status of Umm Saihoun area to understand the actual problems this area face. Also, further research on the status of children who work in their family businesses is recommended. It should aim to explore the reasons behind their work and to help them to go back to school.

\section{References}

Al-Hilalat, K. (2003). The Phenomenon of Child Labour in the Tourism Sector in Petra City. Masters Dissertation, the University of Jordan: Jordan.

Al-Raqqad, S. (2005). The International Perspective of Child Labour and its Application on the National and Regional Standards and Provisions. The Spirit of Laws Journal, 34.

Black, M. (1995). In the Twilight Zone: Child Workers in the Hotel, Tourism and Catering Industry. Geneva: International Labour Organization.

Bliss, S. (2006). Child Labour in Tourism in Developing Countries. Paper presented at The Social Educators' Association of Australia Biennial National Conference, Brisbane.

Brown, G. (2012). Child Labor \& Educational Disadvantage - Breaking the Link, Building Opportunity. London: The Office of the UN Special Envoy for Global Education.

Cole, S. \& Eriksson, J. (2010). Tourism and Human Rights, in Cole, S. and Morgan, N., (ed). Tourism and Inequality: Problems and Prospects. Oxford: CABI

Darweesh, H. (2000) Child Labour and its Relationship with Their Development and Social Upbringing: A study on a specimen of working children and their peers from school students in the governorate of Al-Zarqa, Masters Dissertation, The University of 
Jordan, Amman.

David, F. (2000). Child Sex Tourism. Trends \& Issues in Crime and Criminal Justice, 156.

Department of Statistics. (2012). Jordan Statistical Yearbook 2012. Amman: Department of Statistics.

Department of Statistics \& International Labour Organization. (2008). The National Survey on Child Labour in Jordan (2007-2008). Amman: Department of Statistics.

Funnel, D. (2006). Tourism Ethics. Clevedon: Multilingual Matters Limited.

George, B.P., \& Varghese, V. (2007). Human Rights in Tourism: Conceptualization and Stakeholder Perspectives. Electronic Journal of Business Ethics and Organization Studies, 12(2), 40-48.

Gharaibeh, M., \& Hoeman, S. (2003). Health Hazards and Risks for Abuse among Child Labour in Jordan. Journal of Pediatric Nursing, 18(2), 140-147.

Honey, M., \& Gilpin, R. (2009). Tourism in the Developing World: Promoting Peace and Reducing Poverty. Washington: United States Institute for Peace.

International Labour Organization. (2002). A Future without Child Labour. International Labour Office, Geneva.

International Labour Organization. (2006). Facts on Child Labour, Geneva: International Labour Organization.

International Labour Organization. (2011a). Children in hazardous work, Geneva: International Labour Organization.

International Labour Organization. (2011b). National Labour Law Profile: Jordan. Available http://www.lo.org/ifpdial/informationresources/national-labour-law-profiles/WCMS_158905/lang--en/index.htm

Koenig. K. (2010). Sustainable Tourism in the Context of Poverty Alleviation and Social Business. Paris: HEC Paris Social Business Enterprise and Poverty Chair.

Magabilh, K., \& Naamneh, M. (2010). Child Labour in Tourism Industry in Jordan. Tourism Analysis, 15(1), 89-97.

Ministry of Education. (2007). the National Report on Adult Education in Jordan. Presented to the Sixth International Conference on Adult Education.

Ministry of Tourism and Antiquities. (2012). Tourism Statistical Newsletter, Vol. 8, no. 4, Available http://www.mota.gov.jo/Contents/ Tourism_Statistical_Newsletter_2012Ar.aspx

Novelli, M., \& Hellwig, A. (2011). The UN Millennium Development Goals, Tourism and Development: the tour operators' perspectives. Current Issues in Tourism, 14(3), 205-220.

Saif, I. (2004). Rapid Assessment of the Worst form of Child labour in Jordan: Survey Analysis. Amman: Center for Strategic StudiesUniversity of Jordan,

Sharma, A., Kukreja, S., \& Sharma, A. (2012). Impact of Labour Laws on Child Labour: A case of Tourism Industry. International Journal of Advances in Management and Economics, 1(3), 47-57.

Understanding Children's Work Programme UCR. (2014). the twin challenges of child labour and youth employment in the Arab States: an overview. Beirut: ILO Regional Office for Arab States. 